\title{
Ultrastructural Studies on the Genus Actinomyces
}

\author{
By J. J. DUDA AND J. M. SLACK \\ Department of Microbiology, West Virginia University School of Medicine, \\ Morgantown, West Virginia, 26505, U.S.A.
}

(Accepted for publication 4 January 1972)

\begin{abstract}
SUMMARY
The fine structure of Actinomyces bovis, A. israelii, A. naeslundii, A. odontolyticus and $A$. viscosus was investigated by electron microscopy of chemically fixed and freeze-etched preparations. All species were grown in Brain Heart Infusion broth and examined after 4 and 7 days of growth. The fine structure of all species was similar. The thickness of the wall differed consistently, with $A$. israelii having the thickest. The mode of growth and division was of a uniform pattern. During growth lateral protrusions were formed, followed by two successive cell divisions which were perpendicular to each other and resulted in the formation of cell clusters. Usually these clusters consisted of two rows of cells at approximately right angles.
\end{abstract}

\section{INTRODUCTION}

Ultrastructural studies were done on five species of Actinomyces. They were grown under uniform conditions with the organisms being collected at specified times. Then methods of harvesting, fixing and staining these actinomycetes were determined. Observations on these organisms included wall measurements, a study of cytoplasmic structures, the formation of cell clusters and the process of branching.

\section{METHODS}

Organisms. The following organisms were used in this study: Actinomyces bovis ATCC 13683, A. israelii ATCC I2102, A. naeslundii ATCC I 2 104, A. odontolyticus ATCC 17929, and A. viscosus ATCC I 5987 .

Culture conditions. The organisms were grown in $300 \mathrm{ml}$ of Brain Heart Infusion Broth (BHIB) in an atmosphere of $95 \% \mathrm{~N}_{2}+5 \% \mathrm{CO}_{2}$ at $37^{\circ} \mathrm{C}$ for 4 or 7 days.

Preparation of material for electron microscopy. After incubation, the broth cultures were poured over frozen and crushed BHIB. The bacteria were harvested by centrifugation at $4{ }^{\circ} \mathrm{C}$. The chilled organisms were fixed according to the methods of Kingsbury \& Voelz (I968), Kellenberger, Ryter \& Séchaud (1958), or Falk (1969). The fixed bacteria were embedded in agar, dehydrated through a graded series of ethanol or acetone and then embedded in Epon $8 \mathrm{I} 2$ or Vestopol W. Ultrathin sections were cut with a diamond knife on a Porter-Blum ultramicrotome, lead stained and examined in a RCA-EMU-3G electron microscope.

Purification of walls. Purified walls were prepared from 7 -day cultures by treating the organisms with sodium dodecyl sulphate, alkaline ethyl alcohol and pronase according to the method of Freer et al. (1969).

Freeze-etching. Organisms from 4-day-old cultures were obtained by centrifugation, and suspended in $20 \%$ glycerol in veronal-acetate buffer, $\mathrm{pH} 6 \cdot 0$, for $\mathrm{I}$ h. The sedimented bacteria were freeze-etched in a device designed by McAlear (McAlear \& Kreutizer, 1967). 

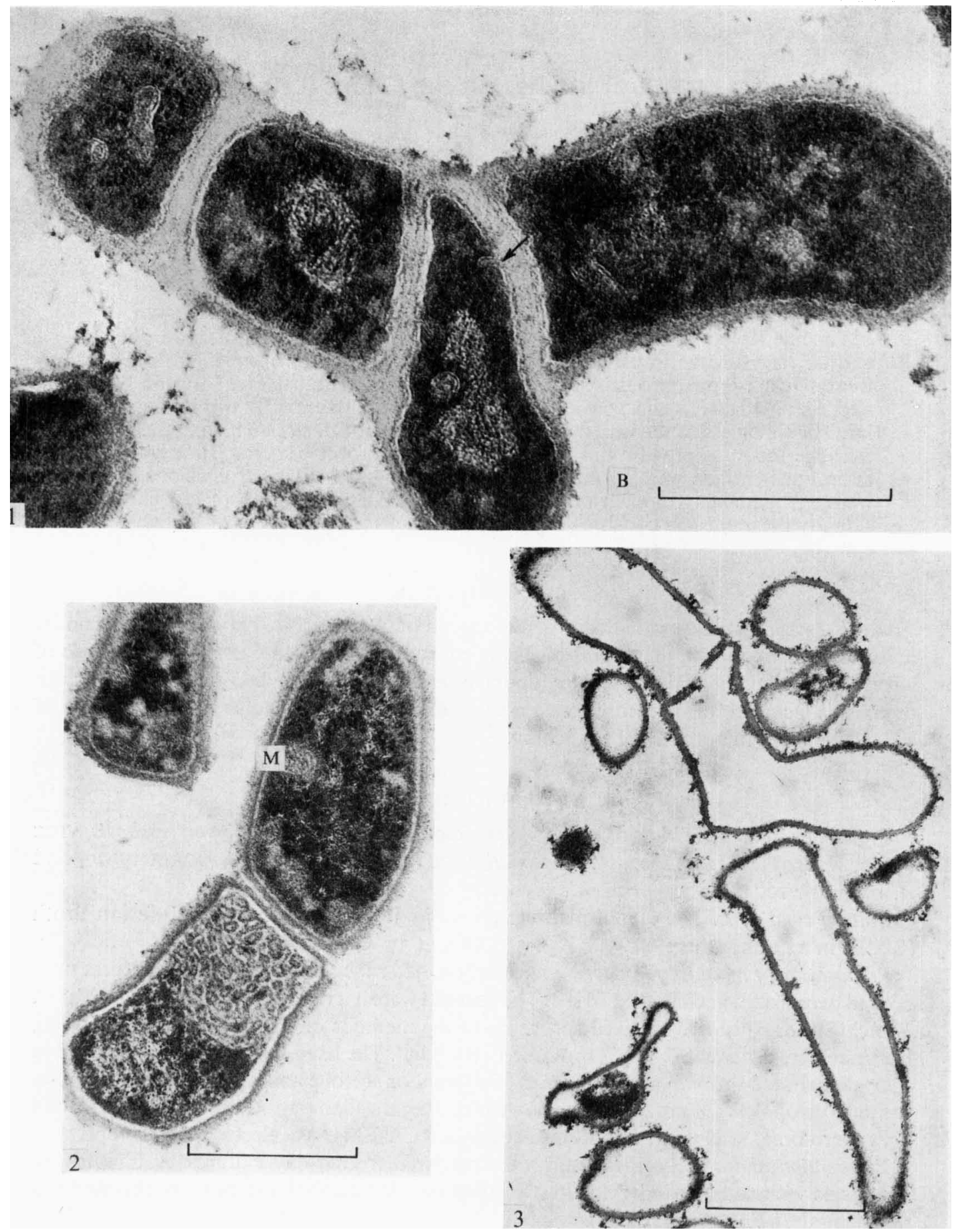

The bar marker in all photographs (except where noted) represents $0.5 \mu \mathrm{m}$.

Fig. I. Cells of 4-day-old Actinomyces odontolyticus, fixed with glutaraldehyde followed by the Kellenberger method. A thick cell wall with a granular material is noted. B, Budding cell; arrow, short membrane invagination.

Fig. 2. Oblique sections through a 4-day-old cell of Actinomyces bovis, fixed by the Kellenberger method. Extensive infolding of the membrane in one daughter cell near the division plane. The other daughter cell contains only one mesosome (M).

Fig. 3. Purified walls of 7-day-old Actinomyces israelii obtained by extraction with alkaline ethyl alcohol and treatment with pronase. The walls have a shaggy outer border, but the double-track structure of the wall is discernible. Bar represents I $\mu \mathrm{m}$. 

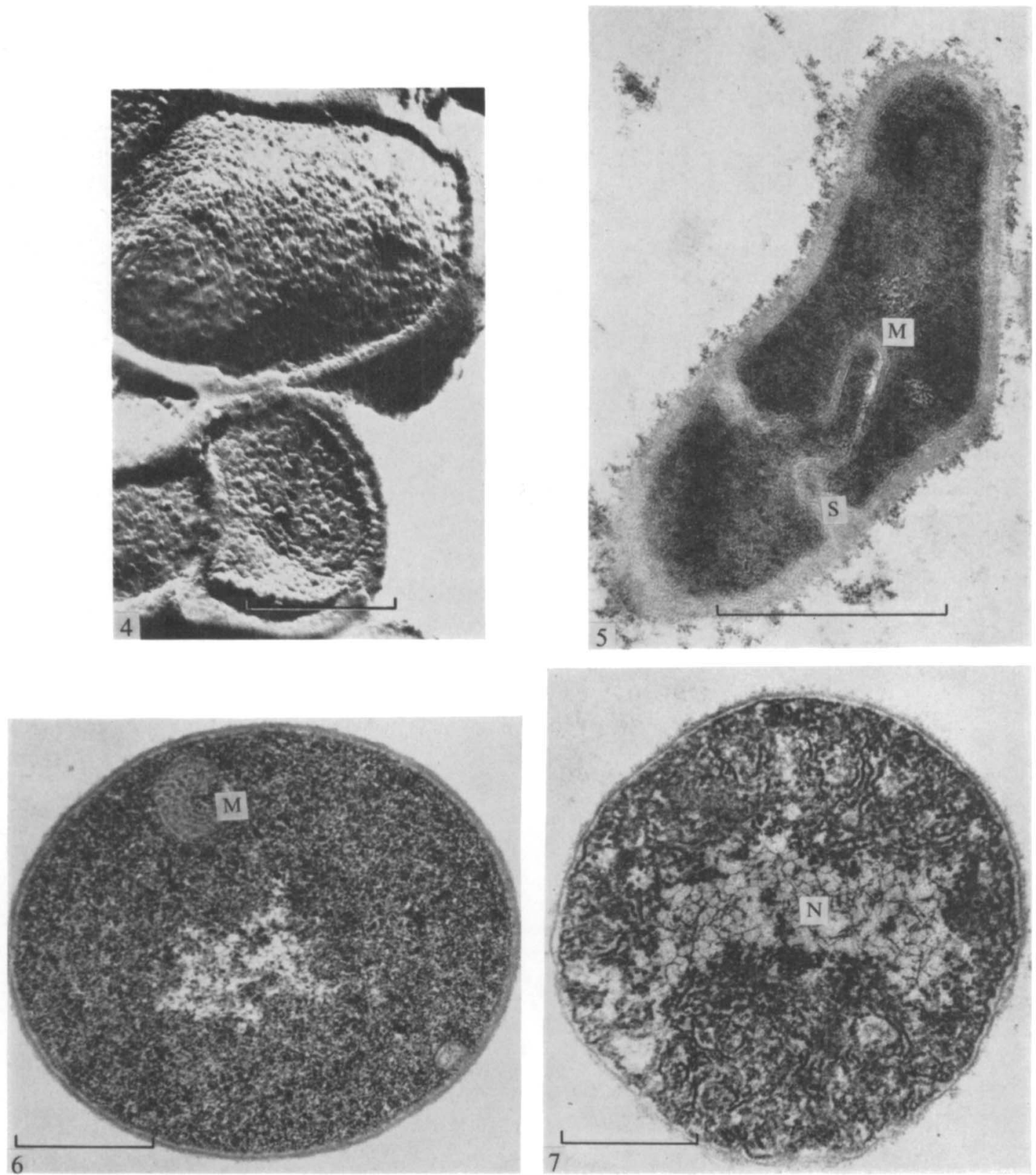

Fig. 4. Freeze-etch preparation of Actinomyces israelii, prepared by addition of $20 \%$ glycerol to the bacteria $\mathrm{I} h$ before freezing.

Fig. 5. Dividing cell of 4-day-old Actinomyces naeslundii, fixed by the Kellenberger method. S, Septa; $M$, advancing growth of membrane.

Fig. 6. Rounded cell of 7-day-old Actinomyces naeslundii, fixed in glutaraldehyde followed by the Kellenberger method. M, Mesosome.

Fig. 7. Degenerating rounded cell. The entire cytoplasm is filled with what appears to be invaginations of the membrane; fixed by the Kellenberger method. Only very few discrete ribosomes can be discerned. The nuclear fibres (N) are loosely distributed within the distended nuclear element. 

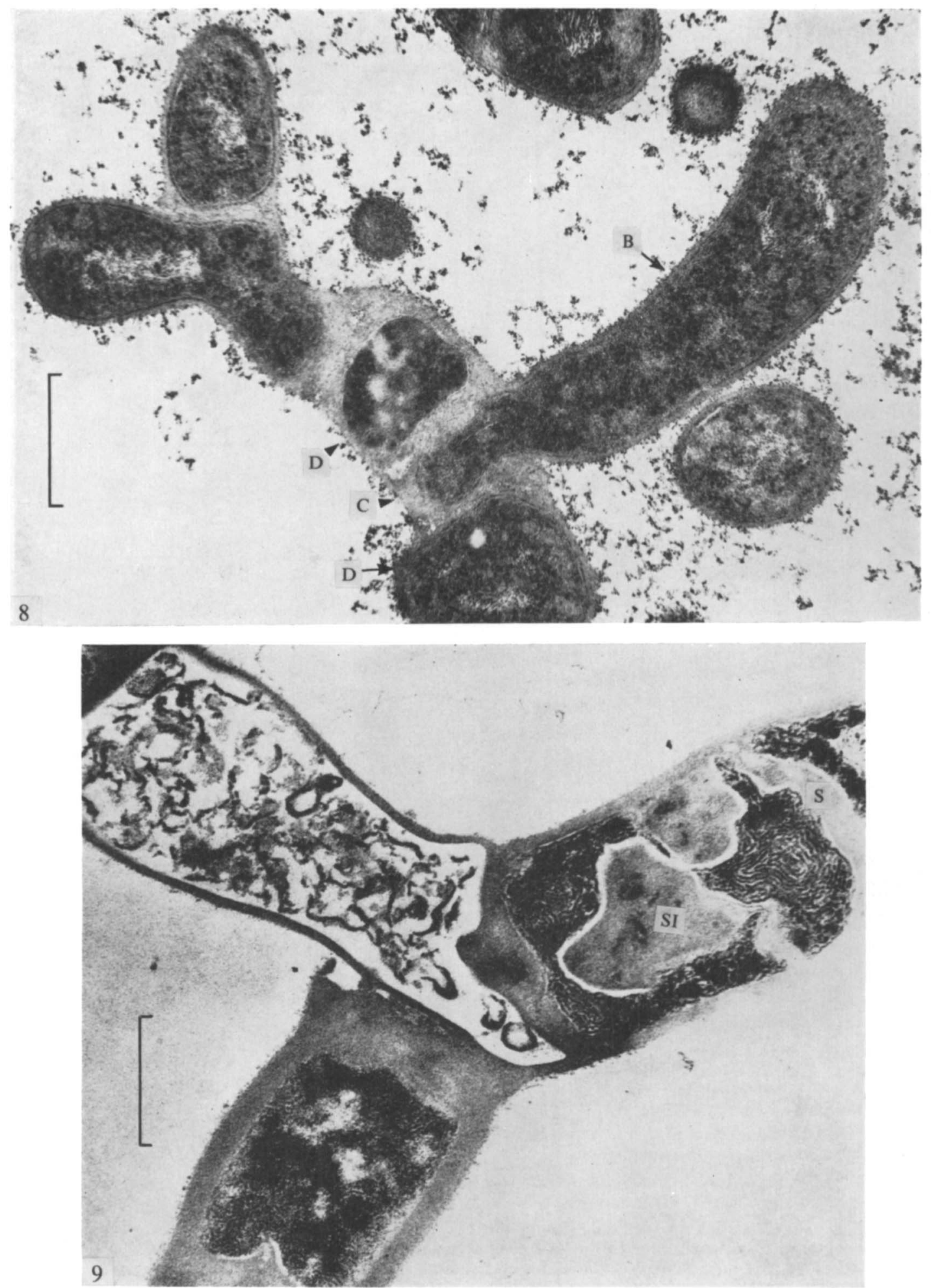

Fig. 8. Cluster of cells of a 4-day-old Actinomyces odontolyticus culture fixed by the Kellenberger method. Note the difference in the width of walls between the 'central' (C) cell and 'derivatives' (D). $B$, 'Budding' cell.

Fig. 9. Cell cluster of a 7-day-old culture of Actinomyces naeslundii, fixed by the Kellenberger method. The cells show various degrees of degeneration. S, Completed septum; SI, incompleted septum. 
Wall measurements. Fixed and unfixed whole organisms as well as purified walls were treated with a wide variety of enzymes but this treatment had no observable effect. Afterwards the thickness of the walls was determined by the methods of DePetris (1965) and Murray, Steed \& Elson (I965). Measurements were made on both unbroken organisms and on purified walls in unfixed, fixed, stained and unstained preparations and included the area between the border of the dense inner layer and the outer edge of the irregular surface.

\section{RESULTS}

Observations on 4- and 7-day-old cultures revealed: (i) single bacteria in various stages of division, and (ii) clusters of two or more cells which were completely divided by cross-walls but not separated into discrete units.

In 4-day cultures, the wall thickness in the different species was approximately $65 \mathrm{~nm}$ for Actinomyces israelii, $45 \mathrm{~nm}$ for $A$. naeslundii, $35 \mathrm{~nm}$ for $A$. viscosus and $3 \mathrm{I} \mathrm{nm} \mathrm{for} \mathrm{both} A$. bovis and $A$. odontolyticus. The outer layer of the wall often appeared granular (Fig. I to 3 ) or 'fuzzy' regardless of the plane of sectioning.

Fig. 4 is a micrograph of a freeze-etched preparation of Actinomyces israelii. Although details of the internal structure cannot be discerned, the thickness of the walls is clearly revealed.

The cytoplasm of actively growing cells was densely packed with ribosomes, and cytoplasmic inclusions were present as electron-opaque or translucent areas (Fig. I, 2). The cytoplasmic membrane was not readily discernible and was tightly associated with the cytoplasm as is typical of Gram-positive organisms. Mesosomes (Fig. 2) were present in each species but the occurrence, number and size varied widely even within single species.

Cell division was by formation of septa (Fig. 5). Frequently that portion of the membrane invaginating at the division plane and initiating cross-wall formation formed folds resembling a mesosome. There was no indication that these structures could aid the completion of the septa. After completion of division there were either no mesosomes in both daughter cells or mesosomes were very elaborately formed in one cell and only sparsely in the other (Fig. 2, 5). Infrequently, rounded organisms were seen in the population. They were not associated with division and invariably contained mesosomes of the tubular type (Fig. 6). In such cells the nuclear element was distended and there were very few ribosomes (Fig. 7).

Cell clusters as in Fig. 8 suggest that division must have occurred in two different planes. First, there was binary fission which resulted in one straight row of bacteria which were divided but not separated. At a right angle from the row, there was always another cell or row of cells which may have resulted from a different mode of division (short arrows). Such outgrowth seemed to be terminated by degeneration of the budding cell or this cell divided by binary fission before degeneration. There was no further proof of division of the daughter cell distal to the 'parent' row of cells (Fig. 8, 9).

\section{DISCUSSION}

These studies of five species of Actinomyces indicate that differences in cytoplasmic structures, which could be used for taxonomic purposes, did not exist. Minor variations in the finer structural details such as invagination of the membrane, were inconsistent among the species or even among cells of the same species. The only consistent differences were in wall thickness. This is in agreement with the findings of Overman \& Pine (I963).

In determining the width of the walls, stringent criteria (DePetris, 1965; Murray et al. 
I965) were applied to eliminate comparisons between: (i) bacteria with fuzzy external layers; (ii) degenerated bacteria with unusually thick walls; (iii) bacteria fixed by different methods. The results obtained were consistent for each species under these given growth conditions. However, since changes in physical and chemical environment can induce profound changes in bacterial walls (Rogers, McConnell \& Burdett, 1968; Garrett, 1969), the possibility exists that the actinomycetes could also exhibit such changes. It is doubtful then, that wall thickness is a reliable differential taxonomic criterion.

Chain growth, i.e. divided, unseparated cells, branching with formation of cell clusters, was a feature consistent in all species. Branching was achieved by buddingof a centre cell in a chain of cells and lateral outgrowth of the budding cell at an angle of about $90^{\circ} \mathrm{C}$. The budding cell then divided, forming another cell chain perpendicular to the direction of growth of the parent cell that gave rise to the cluster. The septa were not always at a right angle to the longitudinal axis of the cell and the completed septa were often curved. Similar observations have been reported for several of the Actinomycetales (Hopwood \& Glauert, 1960; Bradley \& Ritzi, 1968) and for an organism isolated from a case of human leprosy (Freer et al. 1969). If the angle of the septa is genetically controlled this factor could be of taxonomic significance.

This investigation was supported by the Public Health Service grant AI-oI80I from the National Institutes of Allergy and Infectious Diseases. We gratefully acknowledge the interest and assistance of H. G. Voelz in this work.

\section{REFERENCES}

Bradley, S. G. \& RitzI, D. (1968). Composition and ultrastructure of Streptomyces venezuelae. Journal of Bacteriology 95, 2358-2364.

DePetris, S. (1965). Ultrastructure of the cell wall of Escherichia coli. Journal of Ultrastructure Research $\mathbf{1 2}$, 247-262.

FALK, J. (1969). Rough thylakoids: Polysomes attached to chloroplast membranes. Journal of Cell Biology 42, 582-587.

Freer, J., Kim, K. S., Krauss, M. R., Beaman, L. \& Barksdale, L. (1969). Ultrastructural changes in bacteria isolated from cases of leprosy. Journal of Bacteriology 100, 1062-1075.

Garrett, A. J. (1969). The effect of magnesium ion deprivation on the synthesis of mucopeptide and its precursors in Bacillus subtilis. Biochemical Journal 115, 419-430.

Hopwood, D. A. \& GlauerT, A. M. (1960). The fine structure of Streptomyces coelicolor. II. The nuclear material. Journal of Biophysical and Biochemical Cytology 8, 267-278.

Kellenberger, E., Ryter, A. \& Séchaud, H. (1958). Electron microscopic studies of DNA-containing plasms. Journal of Biophysical and Biochemical Cytology 4, 67I-678.

Kingsbury, E. W. \& Voelz, H. (1968). Structural organization of the ribonucleoprotein in Escherichia coli. Journal of Bacteriology 95, I478-I480.

MCAlear, J. H. \& Kreutizer, C. (1967). Freeze-etching with radiant energy in a simple cold block device. Proceedings of the 25th Annual Meeting of the Electron Microscopy Society of America I I6-I 17.

Murray, R. G. E., Steed, P. \& Elson, H. E. (1965). The location of the mucopeptide in sections of the cell wall of Escherichia coli and other Gram-negative bacteria. Canadian Journal of Microbiology Ir, 546-560.

Overman, F. H. \& Pine, L. (1963). Electron microscopy of cytoplasmic structures in facultative and anaerobic Actinomyces. Journal of Bacteriology 86, 656-665.

Rogers, H. J., MCConnell, M. \& Burdett, I. D. J. (I968). Cell wall or membrane mutants of Bacillus subtilis and Bacillus licheniformis with grossly deformed morphology. Nature, London 219, 285. 